\title{
心不全の在宅医療における薬剤師の役割
}

\author{
佐久間詠理, ${ }^{*}, a$ 川 内潤 也, ${ }^{b}$ 行 田 泰 明, ${ }^{c}$ 及川由紀枝, ${ }^{d}$ 渡 邊 淳 子 $a$
}

\section{The Role of Pharmacists in Home Medical Care of Patients with Heart Failure}

\author{
Eri Sakuma, ${ }^{*, a}$ Junya Kawauchi, ${ }^{b}$ Yasuaki Gyoda, ${ }^{c}$ Yukie Oikawa, ${ }^{d}$ and Junko Watanabe ${ }^{a}$ \\ aMedical Corporation Junyuukai Wata Clinic; ARB1F, 1-2-1 Shibamata, Kastushika-ku, Tokyo 125-0052, Japan: \\ ${ }^{b}$ Medical Corporation Wata Home Clinic; Sanyo Garden 2F, 6-8-1 Tateishi, Katstushika-ku, Tokyo 124-0012, Japan: \\ ${ }^{c}$ Medical Corporation Wata Clinic Funabori; T-Garden Square 1303, 3-5-26 Funabori, Edogawa-ku, Tokyo 134-0091, \\ Japan: and ${ }^{d}$ Home Nursing Station Midori; 4-34-13 Tateishi, Kastushika-ku, Tokyo 124-0012, Japan.
}

(Received October 28, 2019)

\begin{abstract}
In recent years, home medical care has been strongly promoted. As a consequence, the conditions managed in home medical care have become increasingly diverse. Heart failure is one of the most common disorders after malignant diseases. Patients with chronic heart failure ( $\mathrm{CHF}$ ) are often forced into hospitalization because of the inability to control symptoms with oral medications, even though they hope to stay at home. Recently, we have experienced a case where the patient required continuous administration of dobutamine at home. In order to carry out CHF care at home successfully, it is necessary to adjust the doses of catecholamine and furosemide swiftly in response to changes in patients' conditions. In this case, the patient was able to spend four months at home thanks to the cooperation of a team of a physician, nurses, and pharmacists. Catecholamine-dependent patients with terminal CHF require expensive medical infusion pumps for precise administration. However, the economic assistance to such patients remains insufficient. Furthermore, dobutamine and furosemide injections are not dispensed extramurally, and therefore might become an impediment to the cooperation of the team. In this symposium, I consider and discuss the role of pharmacists in a home medical care team for patients with terminal CHF.
\end{abstract}

Key words_ - dobutamine; home medical care; chronic heart failure

\section{1. はじめに}

日本における死因別死亡率は，一位の悪性新生物 につぎ，二位が心疾患となつている.11) そのなかで 心不全による死亡は心疾患のなかで最も死亡数が多 い疾患である。日本における心不全患者に関する正 確な統計はないが，推計では2005 年において約 100 万人， 2020 年には 120 万人に達するとされ，今 後高齢化にともない心不全患者数が増加していくこ とが推測される. 2) 心不全の原因疾患は，心筋梗塞

a医療法人社団淳友会わたクリニック（干125-0052 東 京都葛飾区柴又 1-2-1 ARB1F)， ${ }^{b}$ 医療法人社団淳友会 わたホームクリニック（干124-0012 東京都葛飾区立石 6-8-1 三洋ガーデン $2 \mathrm{~F}$ ), c医療法人社団淳友会わたク リニック船堀（†134-0091 東京都江戸川区船堀 3-5$26 \mathrm{~T}$ ガーデンスクエア 1303), $d$ 訪問看護ステーション みどり（干124-0012 東京都葛飾区立石 4-34-13）

*e-mail: eri-sakuma-wata-cl@abox3.so-net.ne.jp 本総説は, 日本薬学会 139 年会シンポジウムS63 で発 表した内容を中心に記述したものである.
や心筋症のように心筋組織が直接的に障害を受けて 心不全を発症する場合，弁膜症や高血圧などにより 心筋組織に長期的に負荷が加わり機能障害から心不 全を発症する場合, 頻脈性ないし徐脈性不整脈によ り血行動態の悪化を招く場合などがある. 心不全の 入院患者の原因疾患は, 虚血性心疾患, 高血圧, 弁 膜症の順である.

心不全の病態変化は, 急性増悪, 回復を繰り返し ながら徐々に進行していく，急性増悪時には入院加 療が必要とされ，回復して心不全のコントロールが 良好となると退院し自宅療養となる。これを繰り返 し, 終末期は自宅に帰れずに入院加療が継続となる ことが多い.

今回，ドブタミン注射薬，高用量のフロセミド注 射薬の投与を継続できれば心不全急性増悪を回避で きる患者の在宅移行を受け入れ，在宅においても注 射薬の投与を継続して心不全のコントロールを行つ た症例を経験した。この症例のような医療依存度の 
高い非がん患者の在宅医療において，在宅の多職種 で構成されるチームの中で，薬剤師が果たすべき役 割について報告する。

\section{2. 心不全の定義・ステージ分類}

心不全とは，「なんらかの心蔵機能障害，すなわ ち, 心臓に器質的およびあるいは機能的異常が生じ て心ポンプ機能の代償機転が破綻した結果，呼吸困 難・倦怠感や浮腫が出現し，それに伴い運動耐容能 が低下する臨床症候群」と定義 ${ }^{2}$ される．現在，病 期の進行については，適切な治療介入を行うことを 目的とするアメリカ心臓病学会/アメリカ心臓協会 (American College of Cardiology/American Heart Association; ACCF/AHA）ガイドラインの心不全 のステージ分類泉が用いられることが多い。急性・ 慢性心不全診療ガイドラインでは, ACCF/AHA の 分類と同様に以下のステージ A-D の分類を定義し ている. ${ }^{4}$

リスク因子を持つが器質的心疾患がなく，心不全 の徵候がない患者を「ステージ A 器質的心疾患の ないリスクステージ」，器質的心疾患を持つが心不 全の徵候がない患者を「ステージ B 器質的心疾患 のあるリスクステージ」，そして器質的心疾患を持 ち心不全の徵候を有する患者を「ステージ C 心不 全ステージ」と分類される，さらにおおむね年間 2 回以上の心不全入退院を繰り返し，有効性が確立し ているすべての薬物治療・非薬物治療について治療 ないしは治療が考慮されたにもかかわらずニュー ヨーク心臓協会（New York Heart Association; NYHA）心機能分類 III 度より改善しない患者を 「ステージ D 治療抵抗性心不全ステージ」とし, これらの患者は, 補助人工心臟や心臟移植などを含 む特別の治療, 若しくは終末期ケアが適応になる.

在宅医療の介入時期は「ステージ C 心不全ステー ジ」で開始することが多い，病院医師と在宅医師の 併診を行うか若しくは急性増悪時の病院の受け入れ が確保された態勢が取られた上で，定期訪問診療を 行い, 心不全の徴候の増悪時に速やかな対応を行う.

\section{3. 心不全の治療}

急性/慢性心不全診療ガイドラインでは，各ス テージにおける治療目標はステージの進行を抑制す ることにあるとし，それぞれのステージの治療目 標・治療を以下の通りとしている。ステージ A (リスクステージ)，ステージ B（器質的心疾患ス
テージ）は心不全発症のリスクステージである，ス テージ A では心不全の原因となる器質的心疾患の 発症予防，ステージ B では器質的心疾患の進展抑 制と心不全の発症予防を目標とする。そしてステー ジC（心不全ステージ）では予後の改善と症状を軽 減することを目標とし，ステージD（治療抵抗性 心不全ステージ）における治療目標は，基本的には ステージ C と同様であるが，終末期心不全では症 状の軽減が主たる目標となる。

それぞれのステージの治療目標を達成するために ステージ毎に治療を実施する．急性心不全として発 症し, 症状の改善後, 慢性心不全としてステージ C に留まる。このような急性増悪を繰り返し，治療に 対する反応がそしくなり，ステージ D に進展す る，ステージCにおける治療には，慢性心不全治 療と急性心不全治療の両方が含まれ，治療は左室駆 出率 (left ventricular ejection fraction; LVEF) の低 下した心不全 (heart failure with reduced ejection fraction； HFrEF） と LVEF の保たれた心不全 (heart failure with preserved ejection fraction; HFpEF）に応じて選択し，LVEF が軽度低下した 心不全 (heart failure midrange ejection fraction; HFmrEF）の治療については, 個々の病態に応じて 判断する.

心不全の経過は，終末期でも一定の時期まで体調 やADL を維持して急激に増悪する悪性腫瘍の経過 とは大きく異なる.

在宅療養において急性増悪時には，内服利尿剤の 増量やフロセミド注射薬，場合によってはカルペリ チドの投与を試みる。それらの薬剤投与でも回復で きない，若しくは家族が強く入院希望の場合は，入 院加療にて適切な処置, 薬物治療が必要であり, そ の後心不全のコントロールが良好となれば在宅へ移 行するが，内服薬に切り替えられない患者もいる. 強心薬を含む心不全治療の注射薬が在宅でも投与が

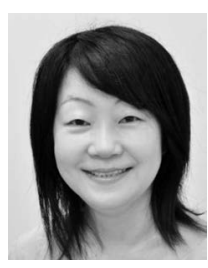

佐久間詠理
1986 年に東邦大学薬学部を卒業し，同 年に明治製菓株式会社に入職し医薬品 の品質管理に携わり, 1987 年に新橋調 剤薬局に入職し調剤業務を行っていた. 1999 年に株式会社水戸薬局に入職し在 宅業務に取り組み, 2013 年に現在所属 の医療法人社団淳友会わたクリニック に入職し，在宅療養支援診療所の院内 薬剤師として勤務している. 
継続できれば，急性増悪を繰り返しステージCか らステージ D に進展する患者が，在宅療養を継続 することが可能となる.

3-1. 慢性心不全の主な薬物治療

3-1-1. アンジオテンシン変換酵素阻害薬（angiotensin-converting-enzyme inhibitor; $\mathrm{ACE}$ 阻害薬)

レニン・アンジオテンシン・アルドステロン系 (renin-angiotensin-aldosterone system; RAA 系) が 賦活されることによって心不全が悪化すると考えら れ，阻害により心不全の予後が改善される，薬剤の 忍容性（咳嗽, 血圧, 血清クレアチニン值, 血清力 リウム值）がある限り，増量を試みる.

3-1-2. アンジオテンシン II 受容体拮抗薬（angiotensin II receptor blocker; ARB) ACE 阻害薬 と同様に RAA 系の阻害により心不全の予後が改善 される。ACE 阻害薬が忍容性などで投与できない 場合に ARBが用いられる.

3-1-3. $\boldsymbol{\beta}$ 遮断薬 カテコラミン $\beta$ 作用を抑制 し，心拍出量の低下，レニン産生の抑制などの作用 を有する. 心保護作用により心不全予後を改善させ る. 投与量を調節して心拍数コントロールを行う. 投与禁忌となる合併症（気管支喘息，糖尿病性ケト アシドーシス・代謝性ケトアシドーシスなど）に注 意する.

3-1-4. 利尿剂 うつ血に基づく労作時呼吸困 難，浮腫の症状を軽減に有効な薬剂である。低カリ ウム血症，低マグネシウム血症に注意する.

3-1-5. 抗不整脈薬重症心室不整脈を抑え, 心不全の突然死を予防することが期待できる. 洞調 律維持や心拍数コントロールの目的で屯用, 又は定 時投与が行われる。

3-1-6. ジギタリス心房細動を伴う心不全患 者に，心拍数をコントロールし十分な左室充満時間 を得るためにはジギタリスを使う。ジゴキシン血中 濃度に比例して死亡率が増加し注意が必要なことか ら, 在宅でも慎重に投与を行い推奨される至適血中 濃度 0.5-0.8 ng/mL のチェックを行う.

3-1-7. 経口強心薬重症例における QOL の 改善目的や, 静注強心薬からの離脱時, $\beta$ 遮断薬の 導入時の使用の有用性が挙げられる.

3-1-8. 抗凝固薬 心不全は血流のうつ滞に よって心臓内血栓をきたし易い。心房細動を伴う場 合は，抗凝固薬が必要である，塞栓症や出血性合併
症は，新規抗凝固薬が有効であり，食事や薬物相互 作用の影響が少なく，血液データのモニタリングが 不要で頻回の採血が必要とされないことから，在宅 では選択され易い薬剂である。心臓内血栓による塞 栓症予防には，ワルファリンの使用が推奨される.

\section{3-2. 急性心不全の主な薬物治療薬}

3-2-1. 塩酸モルヒネ モルヒネは交感神経緊 張の著しい克進を鎮静することによって，細動脈や 体静脈を拡張し，心拍数の減少によって，心筋の酸 素需要は減少する。呼吸器系に対しては, 呼吸回数 の減少，呼吸仕事量の抑制により酸素需要が低下す る。保険適応からモルヒネ塩酸塩錠, モルヒネ塩酸 塩末，モルヒネ塩酸塩注が選択できる.

3-2-2. 利尿剂 ループ利尿薬は, 肺うつ血や 浮腫などの心不全症状を軽減し，前負荷を減じて左 室拡張末期圧を低下させる。急性心不全患者に，そ の即効性は有用である．在宅患者の肺うつ血による 症状の増覀時には，血圧の低下，腎機能障害の発現 に注意しつつ, 利尿剂の内服増量, 注射薬への切り 替え投与を行う.

バソプレシン $\mathrm{V}_{2}$ 受容体拮抗薬はアルギニンバソ プレシンタイプ 2 受容体を阻害する経口薬である. 他の利尿剂に抵抗性を認められる心不全患者に使用 が認められている，急激な水利尿から脱水症状，高 ナトリウム血症を来すことから，入院下での投与開 始又は再開することとなっており，在宅での導入は 適さない.

カルペリチドは，血管拡張作用，ナトリウム利尿 効果，レニン・アルドステロン合成抑制作用によ り，減負荷効果により肺うつ血患者への適応があ り，在宅患者においても急性症状発現時に選択され て投与が行われることがある.

3-2-3. カテコラミン強心薬カテコラミンは アドレナリン受容体と結合して，心筋収縮増強作 用, 心筋弛緩速度増加, 心拍数増加, 刺激電動速度 増加を発揮する。

ドブタミンは $\beta_{1}, \beta_{2}, \alpha_{1}$ 受容体刺激作用を有す る. 他のカテコラミンに比べて, 心筋酸素消費量の 増加が少なく, 虚血性心疾患にも使い易い。「保険 医が投与できる注射薬」の指定を受けていないた め，院外処方はできない薬剤となっているが，医師 が必要と判断し，医師の管理の下で正しく実施され るのであれば，院内からの薬剤の払い出しで投与す 
ることが可能な薬剤である.

\section{4. 緩和ケア}

世界保健機関は緩和ケアの定義5)を，「生命を脅 かす疾患による問題に直面している患者とその家族 に対して，痛みやその他の身体的問題，心理的社会 的問題，スピリチュアルな問題を早期に発見し，改 善するアプローチである」とし，緩和ケアの対象患 者はがん患者に限定されず, 循環器疾患, 呼吸器疾 患患者も対象となっている．急性増悪により入退院 を繰り返す心不全患者にも，早期からの緩和ケアの 導入を行う必要がある。そのためには，意思決定能 力が低下する前に，患者や家族が望む治療と生き方 を多職種によるチームで共有し，アドバンスケアプ ランニングを行うことが重要である．がん患者や家 族は，がんの診断を受けたときからその病期によつ て様々でありながらも死を意識し予後について考え る. それに対して，急性増悪時に入院加療により回 復して退院を繰り返す心不全患者の病態の経過か ら，最期は自宅でと考えていても，病期が終末期に 入った中での増悪時に家族が諦めきれず入院を希望 することが少なくない，病態変化の特徵から心不全 患者の意思決定の難しさが生じる，心不全患者の場 合は，何度も回を重ねて意思を確認する，そのプロ セスが重要となる。

\section{5. 症例報告}

ドブタミン注射薬，高用量のフロセミド注射薬の 投与を継続して在宅移行となつた終末期心不全患者 を受け入れ，在宅においても注射薬の投与継続に よって心不全のコントロールを行い，4 カ月間の自 宅療養を継続できた症例を報告する.

5-1. 患者背景患者は 60 歳代の女性で, 先 天性の心疾患ファロー四徵症を患い, 幼少期から 3 回の手術を受けた。術後肺動脈弁逆流症に伴う慢性 心不全で, 内服の心不全治療薬で心不全のコント ロールを行い, 急性増悪時には入院加療していた。

ドブタミン注射薬を投与してコントロールが良好と なったら内服薬に切り替えて退院し，自宅療養を行 うことを繰り返していた。

5-2. 退院前の経過体重増加, 呼吸困難を認 め, 慢性心不全の急性増悪で入院となっていた，胸 水貯留, うつ血所見を認めたので, うつ血性心不全 の診断となり, 内服薬継続（ジゴキシン，トルバプ タン, トリクロルメチアジド, スピロノラクトン,
イミダプリル）でドブタミン注射薬持続投与を開始 した，それにより尿量が得られ，体重減少，胸水， うつ血が改善した. ドブタミン注射薬，フロセミド 注射薬で尿量が保たれ心不全のコントロールは良好 となった. 前回の退院時には内服薬に切り替え, フ ロセミド, トルバプタン, トリクロルメチアジド, スピロノラクトンの 4 種類の利尿剤を投与する状態 であった．今回明らかな原因がなくわずか数力月で 急性増悪を認め再入院となつた。 その経緯から内服 への切り替えは短期間での再入院が予測されるた め, ドブタミン注射薬持続投与，フロセミド注射薬 を継続で退院する方針となった。

5-3. 退院前カンファレンス 退院前カンファ レンスは 3 回行われ，在宅チームからは在宅医が参 加し, 3 回目に訪問看護師も参加した。病院主治医 は病状からこのタイミングを逃すと今後帰宅するこ とが難しいと考え，「今帰らないと家に帰れなくな るかもしれないよ」と患者に話していた。 しかし患 者，家族は，注射薬持続投与のためのルートが接続 された状態での自宅療養を受け入れ難く, 退院に踏 み切れないままに入院加療を継続していた。1 回目 のカンファレンスでは, 在宅での具体的な医療提供 の提案, 在宅療養のイメージの説明を行った。患 者・家族には，移動が容易にできる軽量の小型ポン プをドブタミンの投与に使用することを説明した が，ポンプを限定した提案ではなかったため具体的 な在宅療養のイメージが湧かず，その表情は硬く患 者，家族が退院に向けて前向きな検討を行うには至 らなかったので，退院は見送られて 1 回目のカン ファレンスは終了した.

そこで， 2 回目のカンファレンスに向けてさらに 具体的な提案を行うための準備を始めた。在宅で使 用されるカフティポンプ $\mathrm{S}^{\circledR}$ と CADD-Legacy ${ }^{\circledR}$ の 2 種の定量ポンプの機能を比較し，ドブタミン注射薬 持続投与に最適なポンプ選択のための検討を行った.

在宅では，主に高カロリー輸液の投与に用いられ るカフティポンプ $\mathrm{S}^{\circledR}$ は，チューブの上流から下流 に向かってローラーでしごくことによって送液を行 い，押し出される間隔は 5 秒間に 1 回と時間の間隔 が一定に保たれていた。 それに対して CADDLegacy ${ }^{\circledR}$ はポンプの底面にあるフィンガが上下して チューブを圧迫して送液を行い，送られる 1 回量が $0.05 \mathrm{~mL}$ と固定され，投与量によって押し出される 
間隔が変化する．例えば， $5 \mathrm{~mL} /$ 時の投与量を設定 した場合, カフティポンプ $\mathrm{S}^{\circledR} 0.4$ 秒で駆動し, 4.6 秒停止が 5 秒間隔で繰り返される。CADDLegacy ${ }^{\circledR}$ は 1 回に押し出される量が $0.05 \mathrm{~mL}$ なので, $5 \mathrm{~mL} /$ 時は 1 時間に 100 回押し出され 36 秒間隔に なる．状態に応じて投与量は変化することが見込ま れるため, 投与量の変化に左右されずに 5 秒間隔の 一定を保ち，なおかつその間隔が短い機能に着目 し, 今回ドブタミン注射薬の投与にカフティポンプ $\mathrm{S}^{\circledR}$ が選択された.

次にドブタミン製剤の選択検討を行った。 中心静 脈カテーテル (central venous catheter; CV カテー テル）からの投与の逆流を防き，定量的に投与を行 うためには, 点滴速度が一定以上の必要があるこ と，また希釈調製を行う負担を軽減できることで, プレミキシング製剤ドブトレックス ${ }^{\circledR} キ ッ ト$ 点滴静 注用を選択した。そしてカフティポンプ $\mathrm{S}^{\circledR}$ に接続 可能な $1000 \mathrm{~mL}$ バッグ（ハイカリック IVH バッ グ®) にドブトレックス ${ }^{\circledR} キ ッ ト$ 点滴静注用 $200 \mathrm{mg}$ を 5 キット充填することで，点滴バッグの頻回交換 を避けることとした。

2 回目のカンファレンスには, 実際に使用するカ フティポンプ $\mathrm{S}^{\circledR}$ を持参し，患者に見せてその機能 の説明を行ったので，患者・家族は在宅療養のイ メージが持てたので在宅移行が前向きとなった。 3 回目のカンファレンスには, 訪問看護師も参加した ことで，生活の中での具体的な在宅医療の説明がで きた．患者は「家に帰つたら外食がしたい」と自宅 療養をイメージし具体的な希望を話した。この 3 回 目で退院を決定することができた. 3 回のカンファ レンス開催・参加は異例であったが，患者・家族が 退院して在宅療養に切り替える決断をするために は，必要なことであった。

5-4. 自宅療養の経過退院した時刻に合わせ て, 在宅医師, 訪問看護師, 診療所薬剤師で訪問を 行つた．患者の退院には，患者の介護タクシーに同 乗した病院看護師から在宅医師に申し送りが行われ 引き継がれた。患者が自宅に着いたら，直ちにバイ タルチェックを行い，速やかにポンプの交換，準備 したドブタミン注射薬，フロセミド注射薬の投与を 行い在宅療養が開始となった.

$\mathrm{CV}$ カテーテルは, トリプルルーメンで 1 カ所は 閉塞して使用できない状態であった。残り 2 力所を
ドブタミン注射薬とフロセミド注射薬のそれぞれの 投与に使用した。 ドブタミン注射薬は適正量が定量 的に持続投与されなければならない. ポンプトラブ ルやルートトラブルでドブタミンの投与が継続でき なくなれば，血圧が保てず，生命の維持が厳しくな る危険性がある。医師はルートの閉塞に注意を払 い, 点滴の速度を $2 \mathrm{~mL} /$ 時以上の設定とし逆流が ないように定量投与を行った.

訪問看護師は 1 日 2 回の訪問を行い, バイタル, 体重，尿量，呼吸状態，浮腫などの所見を観察し医 師に報告した。点滴の準備・実施・管理を行う上 で，ルート感染を避けるために，清潔操作を徹底し た。 その他，清潔援助，精神面の援助，食事の準備 など，訪問看護の限られた時間内で多様な看護を 行った.

在宅医は週 1 回の定期訪問を行い，また状態変化 時に看護師からの報告を受け，必要に応じて臨時の 訪問を行った。患者の状態に応じてフロセミド注の 投与量を増減し, 症状コントロールを行った。 フロ セミドは持続投与で投与量は $120 \mathrm{mg} /$ 日から最終は $500 \mathrm{mg}$ /日まで増量となった。 $300 \mathrm{mg} /$ 日までは 100 $\mathrm{mg} /$ 回のボーラス投与も行った．療養経過の中で心 不全は進行し，ドブタミンの投与量は在宅療養開始 時の $3.75 \gamma$ から最終は $8.75 \gamma$ まで増量した（ $\gamma$ : 薬 剤投与時の速度の単位， $1 \gamma=\mu \mathrm{g} / \mathrm{kg} / \mathrm{min} ） 0.1 \%$ ト ブトレックス $9 \mathrm{~mL} /$ 時から開始し， $15 \mathrm{~mL} /$ 時まで 増量となつた時点で，濃い製剤 $0.3 \%$ ドブトレック スを $5 \mathrm{~mL} /$ 時の投与に切り替えた。内服薬を継続 し，他カリウム・ナトリウムの補正，アルブミンの 投与も行った (Fig. 1).

薬剤師の訪問は，ドブタミン，フロセミドの持続 投与が途切れることのないように，看護師の訪問に 合わせ薬剂を直接看護師に手渡した．訪問時の薬液 交換の際，患者の状態を確認し，設定のダブル チェックを行った。

在宅でのドブタミン注射薬の持続投与が始まる前 に，入院中に長期間ドブタミン注射薬の投与を行 い，その投与量で不整脈の発現がなく安全性が得ら れていたので，循環モ二夕による中心静脈圧や心拍 出量などの測定がなくても, 尿量, 体重, 他臨床所 見のモニタリングを行い薬剤の投与量を調節するこ とで，心不全のコントロールを良好に維持すること ができた，急激な急性増悪を来すことなく，自宅療 


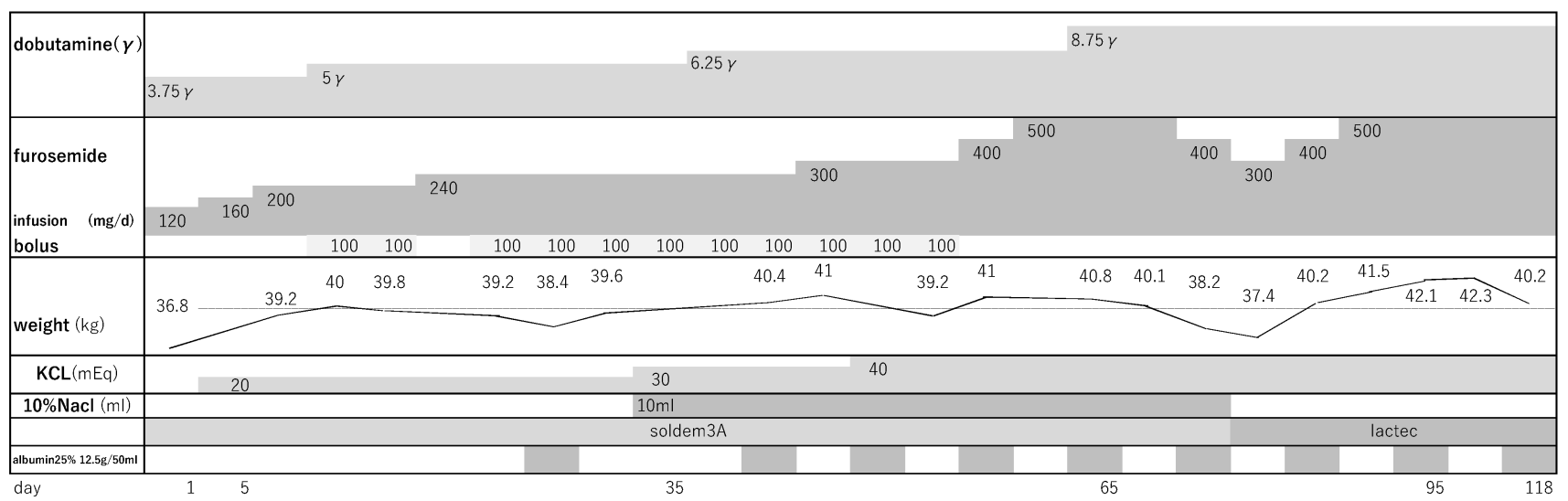

Fig. 1. Drug Treatment Progress at Home

養を 4 カ月間継続することができた.

\section{5-5. 多職種による連携患者の状態に応じて} 利尿剂の投与量の変更が細やかに行われ，指示通り に薬剤が速やかに投与されるためには，医師・看護 師・薬剂師のチームの連携が必要とされた。医師が 患者を訪問して患者の状態に合わせてフロセミド注 射薬の投与量が決定すると, 診療所薬剤師が主治医 から受けた処方を確認し，主治医と調整したのち保 険薬局に処方せんを FAXする。診療所薬剤師から 保険薬局薬剂師に電話にて医師の指示内容の確認を 行った。診療所薬剂師は訪問看護師とも連絡を取 り，医師の指示内容を再度確認し，訪問看護師の訪 問予定時間を保険薬局薬剂師に伝えた。保険薬局薬 剂師は訪問看護師の訪問時間に合わせて薬剤の混注 を行い, 訪問看護師に薬剂を手渡し予定通りに投与 を開始した.このような連携の流れを 2 日毎に行つ た. 利尿剤の投与量の増減に対して, 速やかに対応 できるチームの連携が行われた。医師・看護師・保 険薬局薬剂師・診療所薬剂師の多職種間で, 投与量 のチェックを行うことで, 安全性を担保することが できた.

\section{5-6. チーム内での薬剤師の働き＼cjkstart補液にフロ} セミド注射薬，塩化ナトリウム，塩化カリウムの混 注は, 保険薬局の無菌室において, 薬局薬剤師に よって行われた。フロセミドは $\mathrm{pH} 6.27$ より酸性側 で白濁の性質があることから，混注は混注後の安定 性を確認して行った. ドブタミン製剤は院外処方が できないため, クリニックからの払い出しとなる. クリニックの払い出しになるドブトレックス ${ }^{\circledR} キ ッ$ 卜点滴静注用の $1000 \mathrm{~mL}$ バッグへの充填は診療所
薬剂師が薬局の無菌室を借りて行つた．院外処方薬 は保険薬局薬剂師が，クリニックからの払い出し薬 は診療所薬剤師がそれぞれ無菌調製の担当となり分 けて行った.このように投与注射薬のすべてを無菌 調製で行えたことは, カテーテル感染を発症するこ となく自宅療養が継続できたことに大きく貢献でき たと言える．また，混注や $1000 \mathrm{~mL}$ バッグへの充 填を薬剤師が行うことによって, 訪問看護師は, 薬 液のバッグにルートを差し替えるだけで投与が継続 できた。このように訪問看護師の負担は軽減され, 訪問看護師がケアに集中することができた.

\section{5-7. 介護者の負担慢性心不全の病態変化} は, 急性増悪, 回復を繰り返しながら徐々に進行し ていくため, 介護が長期化し家族の介護負担は大き い.この症例においても, 主介護者である家族が躁

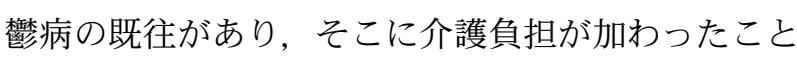
により精神状態が不安定となり在宅療養の継続がで きなくなつたことが，最終入院の理由である．在宅 療養の継続のためには, 家族の介護負担を減らしな がら家族の不安を取り除く必要があった．ケアマネ ジャーを中心に，ヘルパーだけでなく看護師も加わ り生活面での支援を行い，また家族の精神面での フォローも行った. しかし在宅療養中急性増悪の発 現はなくても，進行する心不全の経過において家族 の不安は続き，介護を継続することが不可能な状態 となつた. 心不全のコントロールが維持できていた にもかかわらず，再入院を選択することになったこ の事例から，家族の精神面の支援を含めた介護支援 は，在宅療養を継続するためには重要となることを 学んだ. 
5-8. 厚生労働大臣が定める「保険医が投与可能 な注射薬」の指定フロセミド注射薬，ドブタミ ン注射薬は「保険医が投与可能な注射薬」の指定を 受けていないため, 院外処方ができない薬剤であ る. 院内からの持ち出しとなり，薬局薬剂師がその 供給に係わり難い現状である。 さらに管理料の問題 もある. ドブタミン投与において，管理料の算定が なく，ポンプ加算の対象ともならないためポンプ使 用に当たつて負担が生じる. 同じく心不全終末期に モルヒネの持続投与となったときに，がん患者にお ける投与では，管理料が保険算定できるのに対し て，心不全患者の投与には管理料の算定がないた め，ポンプ使用に当たって負担が生じる．このよう な解決すべき問題点が挙げられる.

\section{6. おわりに}

多くの患者は自宅に帰ることを望むが，入院加療 と住夕慣れた自宅での療養には，それぞれの利点と 欠点がある。入院加療の利点は病態の把握がし易 く，病態変化への対処が速やかに行える．また，完 全看護のため家族負担は少ない，尔点としては，自 然な形での日常生活ができず，面会時間の制限があ り，家族と過ごす時間が取り難い。それに対して自 宅療養は，家族との時間が持て，自然な日常生活を 送ることができるが，病態の把握が困難で，急変時 の対応は病院より遅れてしまうことがある。また家 族の介護負担も生じる。在宅療養は，住夕慣れた自 宅で，自分のペースで生活でき，家族とともに過ご すことで家族の中で自分の役割を果たすことができ る. 患者の生活を豊かなものにする.

心不全の急性増悪時に入院加療でドブタミン注射 薬の投与により安定化しても，終末期心不全患者は 経口薬のみでは心不全のコントロールの安定を維持 できず，自宅に帰ることができない事例が多い，今 回の症例のように，ドブタミン注射薬，高用量のフ ロセミド注射薬を在宅で投与して心不全のコント ロールを行うことができれば，自宅療養を希望とす る終末期心不全患者の願いを叶えることができる. 今後これらの薬剤の院外処方が可能となれば，保険 薬局薬剤師が心不全治療の内服薬から注射薬まで, 供給にしっかりと係わることができ，現状の他職種
の負担軽減が行える。また，保険薬局薬剤師が薬剤 の性質から混注の可・不可を考え，適正な投与ルー トの検討に加わるなど，チームの中で薬学的な介入 を行い，薬剤師としての専門的な役割を果たすこと で，提供する医療の質が上がり，結果として患者に 安心をもたらすことになる。薬剤師を含む多職種の チームが全人的に患者・家族を支えて提供する医療 の質が上がれば，高齢化により増加が見込まれる心 不全患者が，自宅で安心して療養を行うことができ るだろう。

謝辞水戸薬局のスタッフの皆様には，本症例 の連携において，多大なるご協力を頂きましたこと を，心より感謝申し上げます。また，訪問看護ス テーションタどりの看護師の皆様，わたクリニック スタッフメンバーには本論文の作成にあたり，ご指 導ご協力を頂き，ここに感謝いたします。

利益相反＼cjkstart開示すべき利益相反はない.

\section{REFERENCES}

1) Ministry of Health, Labour and Welfare, Summary of Annual Vital Statistics Report (Preliminary Data), 2018: 〈https://www. mhlw.go.jp/toukei/saikin/hw/jinkou/geppo /nengai18/dl/gaikyou30.pdf $\rangle$, cited 5 May 2019.

2) Okura Y., Ramadan M. M., Ohno Y., Mitsuma W., Tanaka K., Ito M., Suzuki K., Tanabe N., Kodama M., Aizawa Y., Circ. J., 72, 489491 (2008).

3) Yancy C. W., Jessup M., Bozkurt B., et al., Circulation, 128, e240-e327 (2013).

4) The Japanese Circulation Society, The Japanese Heart Failure Society, "Guidelines for Diagnosis and Treatment of Acute and Chronic Heart Failure, 2017, pp. 9-12.

5) WHO Definition of Palliative Care, 2002: 〈https://www.jspm.ne.jp/proposal/proposal. html $\rangle$, Japanese Society for Palliative Medicine Web, cited 25 May 2019. 